\title{
Article
}

\section{Anti-Aging Effects of Polyoxometalates on Skin}

\author{
Katsuyuki Fujinami 1,2,*D, Katsuaki Dan ${ }^{3}$, Toshiko Tanaka-Kagawa ${ }^{2}$ and Ikuo Kawamura ${ }^{2}$ \\ 1 FSX, Inc., 1-12-3, Izumi, Kunitachi, Tokyo 186-0012, Japan \\ 2 Department of Health Medicine, Yokohama University of Pharmacy, 601, Matano-cho, Totsuka-ku, \\ Yokohama 245-0066, Japan; t.kagawa@hamayaku.ac.jp (T.T.-K.); ikuo.kawamura@hamayaku.ac.jp (I.K.) \\ 3 Division of Research and Development, Research Organization of Biological Activity, Crest \#301, 3-44-13, \\ Minami-ohtsuka, Toshima-ku, Tokyo 170-0005, Japan; kdan@iyakushigen.jp \\ * Correspondence: katsu@fsx.co.jp; Tel.: +81-(0)42-576-9131
}

Citation: Fujinami, K.; Dan, K.; Tanaka-Kagawa, T.; Kawamura, I. Anti-Aging Effects of Polyoxometalates on Skin. Appl. Sci. 2021, 11, 11948. https://doi.org/10.3390/app112411948

Academic Editors: Adam Kraszewski, Joanna Romanowska and Michal Sobkowski

Received: 18 November 2021 Accepted: 8 December 2021 Published: 15 December 2021

Publisher's Note: MDPI stays neutral with regard to jurisdictional claims in published maps and institutional affiliations.

Copyright: (c) 2021 by the authors. Licensee MDPI, Basel, Switzerland. This article is an open access article distributed under the terms and conditions of the Creative Commons Attribution (CC BY) license (https:// creativecommons.org/licenses/by/ $4.0 /)$.

\begin{abstract}
Excessive reactive oxygen species (ROS) generation by inflammation and glycation contributes to various aging-related changes in the body. Therefore, inhibiting ROS production can prevent wrinkles, maculae, dullness, and slackness in skin. To assess the anti-aging effects of two polyoxometalates (PMs: VB2 and VB3) on skin, this study investigated whether they ameliorated the anti-aging responses of normal human dermal fibroblasts (NHDF) to oxidative stress due to ad-vanced glycation end products (AGEs) or $\mathrm{H}_{2} \mathrm{O}_{2}$ exposure. Compared with the mRNA expression levels of AGE receptors in cells exposed to AGEs alone, an additional treatment with VB2 or VB3 significantly increased the expression levels of FEEL-1, FEEL-2, and RAGE. Under AGE-induced stress conditions, the expression levels of five heat shock proteins were markedly increased by the VB treatments. Conversely, VBs suppressed the induction of cell death and intracellular ROS production. VBs also exerted prophylactic effects on these harmful events under stress conditions. Furthermore, VB treatments were found to prevent both the suppression of AQP-1/AQP-3 expression and the suppression of hyaluronan and elastin production induced via $\mathrm{H}_{2} \mathrm{O}_{2}$ exposure. These results show the potential of VB2 and VB3 as anti-aging agents.
\end{abstract}

Keywords: polyoxometalate; oxidative stress; $\mathrm{H}_{2} \mathrm{O}_{2}$; reactive oxygen species; advanced glycation end product; superoxide dismutase; hyaluronan; aquaporin

\section{Introduction}

Glycation, oxidation, and chronic inflammation are 3 major aging-related reactions, and reactive oxygen species (ROS), which are generated and accumulate at the sites of these reactions, have been shown to induce various aging phenomena [1-5]. Because these aging-related reactions occur in skin, the suppressed generation of ROS is considered to be effective for preventing wrinkles, maculae, dullness, and slackness [6].

Glycation is a non-enzymatic chemical reaction by which sugar molecules or glucose metabolism intermediates (e.g., glyceraldehyde) adhere to amino acid residues in various proteins and eventually generate advanced glycation end products (AGEs) [7]. AGEs play significant roles not only in aging phenomena in the entire body, but also in a wide variety of diseases. For example, collagen in skin is naturally glycated and, thus, the amount of glycation products increases with age. Increases in AGEs have been suggested to play a causative role in diabetes based on the finding showing that their content in cutaneous collagen was higher in diabetic patients than in healthy age-matched individuals [8]. Moreover, the formation and accumulation of AGEs in cells have been implicated in skin aging [8], Alzheimer's disease [9], hypertension [10], arteriosclerosis [11], and osteoporosis [12].

AGEs are produced under specific pathological conditions, such as oxidative stress, and function as proinflammatory mediators. They affect nearly every type of cell in the body. Many of the cellular effects of AGEs involve two different types of AGE receptors; one type has been implicated in inflammation and ROS generation through its activation 
of intracellular signal pathways, while the other type is involved in the degradation and elimination of AGEs through receptor-mediated endocytosis and lysosome-dependent proteolysis (Figure 1). The effects of the former AGE receptors need to be suppressed, while those of the latter need to be promoted to prevent or delay cellular senescence. AGE receptors in the former group include the receptor for advanced glycation end products (RAGE) and AGE receptor 2 (AGE-R2), and those in the latter group include fasciclin EGF-like, laminin-type EGF-like, link domain-containing scavenger receptor-1 (FEEL-1), FEEL-2, AGE-R1, AGE-R3, and CD36.

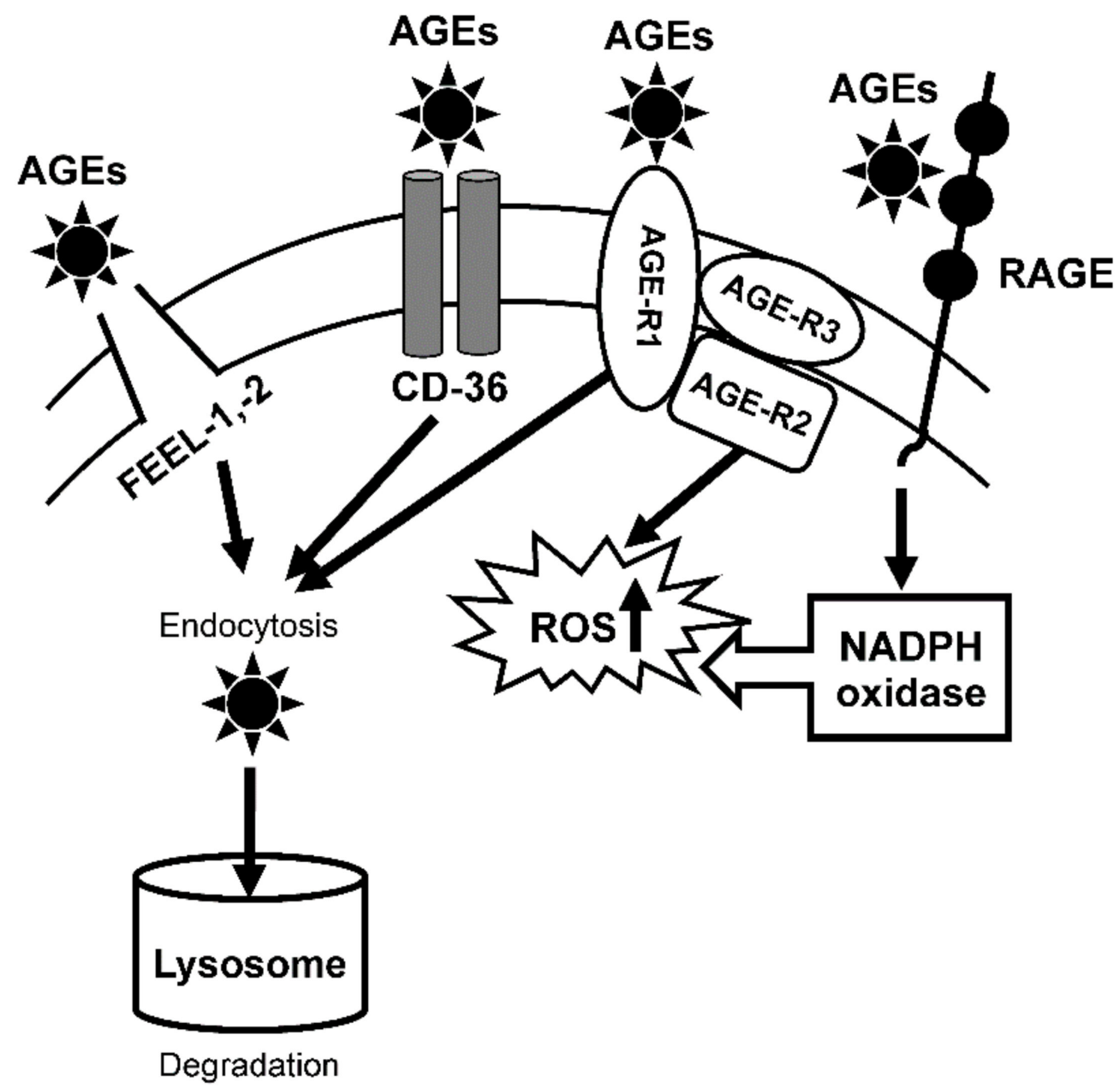

Figure 1. AGE receptors expressed in NHDF and their roles in intracellular events under stress conditions.

Among AGE receptors AGE-R1, FEEL-1, FEEL-2, and CD-36 contribute to the endocytosis of extracellular AGEs into cells and their degradation through phagosome-lysosome fusion. Other AGE receptors, such as AGE-R2, AGE-R3, and RAGE, increase intracellular ROS generation directly or indirectly through the activation of NADPH oxidase.

Damage to DNA, proteins, and lipids, which is caused by ROS generated under oxidative stress conditions, is a major cellular event that has been strongly implicated in accelerated aging and the development and exacerbation of geriatric diseases $[7,13]$. Therefore, it is important to suppress the accumulation of ROS and augment the levels of antioxidants, such as superoxide dismutase (SOD), to control the aging process [14]. Furthermore, aquaporin (AQP)- 1 and AQP-3, which control the permeability of water molecules in the cell membrane, as well as hyaluronan and elastin participate in the moisturization and anti-aging of skin. The expression levels of AQP- 1 and AQP-3 have been shown to decrease under oxidative stress conditions [15]. The degradation of elastin, a core protein of elastic fibers, is regarded as a cause of wrinkle formation, while its sustainable and adequate production is closely involved in skin regeneration $[16,17]$. Therefore, it 
is important to maintain these molecules under stress conditions to suppress the aging phenomena in skin.

Several hundred polyoxometalates (PMs), which are metal oxides that form several structures, have been synthesized to date, and some exhibit anti-neoplastic, anti-viral, and anti-bacterial activities [18]. We previously identified 2 PMs (VB2 and VB3) with strong anti-bacterial and anti-viral activities and demonstrated that they inhibited the adhesion and invasion of viruses into cells by binding to viral particles [19]. The development of products with excellent hygienic properties may be possible by incorporating stable and anti-microbial PMs into materials [20].

In the present study, we examined the effects of PMs (VB2 and VB3) on the stress response of human cutaneous fibroblasts to AGEs and hydrogen peroxide $\left(\mathrm{H}_{2} \mathrm{O}_{2}\right)$ and evaluated their anti-aging activities.

\section{Materials and Methods}

\subsection{PMs}

Bulk powders of VB2 $\left(\mathrm{K}_{11} \mathrm{H}\left[(\mathrm{VO})_{3}\left(\mathrm{SbW}_{9} \mathrm{O}_{33}\right)_{2}\right] \cdot 27 \mathrm{H}_{2} \mathrm{O}\right)$ and VB3 $\left(\mathrm{Na}_{2}\left[\mathrm{SbW}_{9} \mathrm{O}_{34}\right] \cdot 19 \mathrm{H}_{2} \mathrm{O}\right)$ were synthesized using our patented method (international patent publication number: WO2019/230210). Each bulk powder was ground in a mortar, dissolved in ultrapure water, and the solution was used in experiments after being passed through a $0.45-\mu \mathrm{m}$ filter.

\subsection{Materials}

DL-glyceraldehyde and $\mathrm{H}_{2} \mathrm{O}_{2}$ were purchased from Wako Pure Chemical Industries Ltd. (Osaka, Japan). Bovine serum albumin (BSA) (Fraction V) was purchased from SIGMA (St. Louis, MO, USA).

\subsection{Glycation of $B S A$}

AGEs were prepared as previously described [21]. BSA (25 mg/mL) was incubated with $0.1 \mathrm{M}$ DL-glyceraldehyde in phosphate-buffered saline, $\mathrm{pH} 7.4$ (PBS), at $37^{\circ} \mathrm{C}$ for 7 days, and used as AGEs in experiments.

\subsection{Cell Cultures}

Normal human dermal fibroblasts (NHDF) derived from juvenile foreskin (C-12300, PromoCell, Sickingenstr. 63/65, 69126 Heidelberg, Germany) were cultured using special fibroblast growth medium (C-23010, PromoCell, Sickingenstr. 63/65, 69126 Heidelberg, Germany) at $37{ }^{\circ} \mathrm{C}$ in $5 \% \mathrm{CO}_{2}$.

\subsection{Effects of VBs on the mRNA Expression of AGE Receptors and Heat Shock Proteins (Hsps) in} Cells Treated with AGE

NHDF were treated with AGE $(100 \mu \mathrm{g} / \mathrm{mL})$ in the presence or absence of $10 \mu \mathrm{g} / \mathrm{mL}$ VBs at $37{ }^{\circ} \mathrm{C}$ for $4 \mathrm{~h}$ and total RNA was extracted from cells using TRIzol reagent (Ambion). The mRNA expression levels of AGE receptors and Hsps were measured using the quantitative reverse transcription-polymerase chain reaction (qRT-PCR) method.

\subsection{Effects of VBs on the mRNA Expression of AQP-1 and AQP-3 in Cells Treated with $\mathrm{H}_{2} \mathrm{O}_{2}$}

To assess the therapeutic effects of VBs under oxidative stress conditions, NHDF were treated with $0.2 \mathrm{mM} \mathrm{H}_{2} \mathrm{O}_{2}$ for $2 \mathrm{~h}$, washed with PBS, and then cultured with $10 \mu \mathrm{g} / \mathrm{mL}$ VBs for $4 \mathrm{~h}$. To evaluate their prophylactic effects, cells were treated with $10 \mu \mathrm{g} / \mathrm{mL}$ VBs for

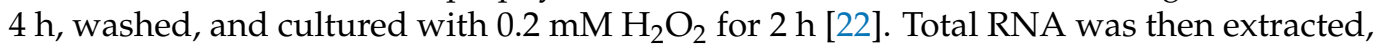
and the expression of mRNAs was examined by qRT-PCR.

\section{7. $q R T-P C R$}

The mRNA levels of AGE receptors, including RAGE, FEEL-1 (Stabilin-1), FEEL2 (Stabilin-2), CD-36, AGE-R1, AGE-R2, and AGE-R3, those of Hsps, such as Hsp104, gp96, Hsp90, Hsp70, Hsp60, and Hsp32, and those of AQP, including AQP-1 and AQP- 
3, in NHDF were measured using one-step qRT-PCR and specific primer sets (Table 1). The mRNA level of glyceraldehyde-3-phosphate dehydrogenase was also measured as an internal control [23-28]. One-step RT-PCR, in which cDNA synthesis by a reverse transcription reaction and qPCR may be performed in a single test tube using total RNA (500 ng) as the template for PCR, was conducted using the Luna Universal One-Step qRT-PCR Kit. The PCR system used was Takara Thermal Cycler Dice Real Time System II. Luna Universal One-Step Reaction Mix $(2 \times), 10 \mu \mathrm{L}$, Luna WarmStart RT Enzyme Mix $(20 \times), 1 \mu \mathrm{L}$, a forward primer $(10 \mu \mathrm{M}), 0.8 \mu \mathrm{L}$, a reverse primer, $0.8 \mu \mathrm{L}$, and template RNA were mixed in a single reaction system, and the total volume was adjusted to $20 \mu \mathrm{L}$ with nuclease-free water. The reaction consisted of 1 cycle at $95^{\circ} \mathrm{C}$ for $30 \mathrm{~s}$ and 50 cycles at $95^{\circ} \mathrm{C}$ for $5 \mathrm{~s}$ and then at $60^{\circ} \mathrm{C}$ for $30 \mathrm{~s}$. A 4 -fold or greater change in mRNA expression $(2$ cycles of PCR) was judged to be significant.

Table 1. Primers for PCR.

\begin{tabular}{|c|c|c|}
\hline Target & Primer & References or NCBI Reference Sequence \\
\hline \multirow[t]{2}{*}{ FEEL-1 (Stabilin-1) } & Forward: AGG ACT GCC GCT ACG AAG TA & 18 \\
\hline & Reverse: CAC TGC CCT GCT GTG TGT AG & \\
\hline \multirow[t]{2}{*}{ FEEL-2 (Stabilin-2) } & Forward: TCT GAA GGC AGG TCT CAC CTA & 18 \\
\hline & Reverse: CTG GGG AGC AGA AAT TTT GTA & \\
\hline \multirow[t]{2}{*}{ CD-36 } & Forward: GAG AAC TGT TAT GGG GCT AT & 19 \\
\hline & Reverse: TTC AAC TGG AGA GGC AAA GG & \\
\hline \multirow[t]{2}{*}{ AGE receptor-1 } & Forward: GTG GGA AAA TGG CAC AAC TT & 20 \\
\hline & Reverse: CTG GCC ACG TCC CTA TTT TA & \\
\hline \multirow[t]{2}{*}{ AGE receptor-2 } & Forward: AGG GCC GTA AGG AGA GAG AG & 21 \\
\hline & Reverse: GTG GCG TCT GTC TGT GTG TC & \\
\hline \multirow[t]{2}{*}{ AGE receptor-3 } & Forward: GAT AAC AAT TCT GGG CAC GG & 21 \\
\hline & Reverse: TGG AGC ACT GGT GAG GTC TAT G & \\
\hline \multirow[t]{2}{*}{ RAGE } & Forward: GAA ACT GAA CAC AGG CCG GA & 22 \\
\hline & Reverse: CAC GGA CTC GGT AGT TGG AC & \\
\hline \multirow[t]{2}{*}{ Hsp-104 } & Forward: TCA TCG ACA AGG ACA GCA AG & NM0012583 \\
\hline & Reverse: GGC TGT GAG GAG GTA AGC AG & \\
\hline \multirow[t]{2}{*}{ gp96 } & Forward: TGG GAA GAG GTT CCA GAA TG & AJ890084.1 \\
\hline & Reverse: GTT GCC AGA CCA TCC GTA CT & \\
\hline \multirow[t]{2}{*}{ Hsp-90 } & Forward: TGG ACA GCA AAC ATG GAG AG & BC121062 \\
\hline & Reverse: AGA CAG GAG CGC AGT TTC AT & \\
\hline \multirow[t]{2}{*}{ Hsp-70 } & Forward: AGT GGT GGC CAC TAA TGG AG & BC112963 \\
\hline & Reverse: CAA TCC TTG CTT GAT GCT GA & \\
\hline \multirow{2}{*}{ Hsp-60 } & Forward: GCA ATG TGT CCA GAG CAA GA & AF143723.1 \\
\hline & Reverse: AAG CTC AAC AGC TGG GAA AA & \\
\hline \multirow[t]{2}{*}{ Hsp-32 } & Forward: TCC GAT GGG TCC TTA CAC TC & NM002133.2 \\
\hline & Reverse: TAA GGA AGC CAG CCA AGA GA & \\
\hline \multirow[t]{2}{*}{ AQP-1 } & Forward: TCT GTA GCC CTT GGA CAC CT & 23 \\
\hline & Reverse: CAA AGG ACC GAG CAG GGT TA & \\
\hline \multirow[t]{2}{*}{ AQP-3 } & Forward: TGC TAC CTA CCC CTC TGG AC & 23 \\
\hline & Reverse: GCC AGC ACA CAC ACG ATA AG & \\
\hline GAPDH & Forward: AGG GCT GCT TTT AAC TCT GGT & 22 \\
\hline
\end{tabular}

\subsection{Effects of VBs on Cell Viability under Oxidative Stress Conditions}

To examine the effects of VBs on cell viability under oxidative stress conditions, cells were treated as described in Section 2.6 of the Materials and Methods and cultured for another $18 \mathrm{~h}$ in special fibroblast growth medium. Cells were collected and viability was measured using the cell counting kit-8 (DOJINDO, Tokyo, Japan). 


\subsection{Measurement of Intracellular ROS Production}

Intracellular ROS were measured by fluorometry using dichlorofluorescein diacetate (DCF-DA; Invitrogen, Carlsbad, CA, USA). Cells were treated as described in Section 2.6 of the Materials and Methods, washed with PBS, and incubated with $10 \mu \mathrm{M} \mathrm{DCF-DA}$ at $37^{\circ} \mathrm{C}$ for $20 \mathrm{~min}$. Intracellular ROS levels were assessed by measuring the intensity of fluorescence at an excitation wavelength of $525 \mathrm{~nm}$ using a microplate reader (SYNERGY/HT, BioTek, Tokyo, Japan).

\subsection{Measurement of SOD Production}

SOD was measured using a SOD Assay Kit (Cayman Chemical, Ann Arbor, MI, USA). After being treated with VBs and $\mathrm{H}_{2} \mathrm{O}_{2}$, as described in Section 2.6 of the Materials and Methods, cells were cultured for $24 \mathrm{~h}$ in special fibroblast growth medium and homogenized after the addition of lysis buffer. After centrifugation, $10 \mu \mathrm{L}$ of the sample was mixed with $200 \mu \mathrm{L}$ of xanthine oxidase at room temperature, and absorbance at $450 \mathrm{~nm}$ was measured after $30 \mathrm{~min}$.

\subsection{Evaluation of the Production of Hyaluronan and Elastin}

After cells had been treated with VBs and $\mathrm{H}_{2} \mathrm{O}_{2}$ as described in Section 2.6 of the Materials and Methods, the quantification of hyaluronan in the culture supernatant was performed using the Hyaluronan Enzyme-Linked Immunosorbent Assay kit (R\&D systems., Inc., Minneapolis, MN, USA). To measure the production of elastin, cells were lysed, and a clear lysate was prepared. The amount of elastin in the lysate was quantified using the Human Soluble Elastin ELISA Kit (Aviscera Bioscience Inc., SK00806-01, Santa Clara, CA, USA).

\subsection{Statistical Analysis}

All experiments were done in triplicate. Results are presented as the mean $\pm \mathrm{SD}$. The significance of differences was examined using the Student's $t$-test, and differences were considered to be significant when $p<0.05$.

\section{Results}

\subsection{Anti-Aging Effects of VBs in an AGE-Induced Stress Environment}

\subsubsection{Expression of AGE Receptor mRNAs}

We demonstrated that VB2 and VB3 both exhibited significant anti-microbial activities against various human pathogens by binding to microorganisms with high affinity and interfering with interactions with host cells. To further clarify the abilities of VBs for functional multipotency, we herein attempted to examine the anti-aging effects of VBs on skin. NHDF were cultured with VBs under stress conditions and the levels of various parameters related to anti-aging phenomena were measured. NHDF are important cells that are present in the dermis and influence the condition of the epidermis along with epidermal keratinocytes. When NHDF were cultured with serially diluted VB2 or VB3 alone, no significant changes were observed in the mRNA expression levels of AGE receptors. However, the treatment with AGE induced the expression of most AGE receptors in skin fibroblasts. In comparisons with the mRNA expression levels of AGE receptors in response to AGEs alone, an additional treatment with VB2 or VB3 markedly increased their levels. The mRNA expression levels of FEEL-1, FEEL-2, and RAGE markedly increased (Figure 2). 


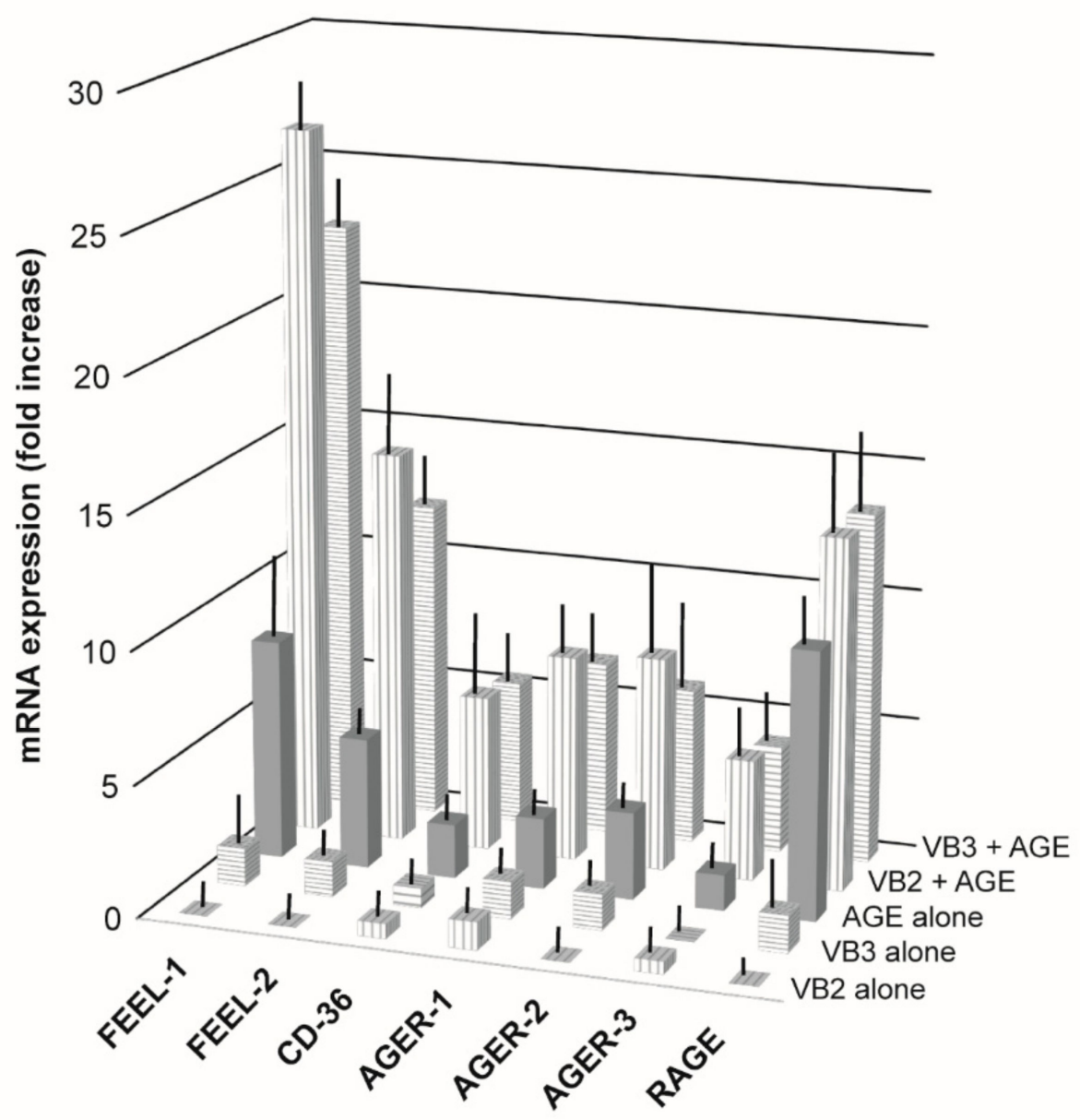

\begin{tabular}{|c|c|c|c|c|c|c|c|c|}
\hline \multicolumn{2}{|c|}{ t-test } & FEEL-1 & FEEL-2 & CD-36 & AGER-1 & AGER-2 & AGER-3 & RAGE \\
\hline \multirow[t]{5}{*}{ Control vs } & VB2 alone & ns & ns & ns & ns & ns & ns & $\mathrm{ns}$ \\
\hline & VB3 alone & $\mathrm{ns}$ & ns & ns & ns & ns & ns & ns \\
\hline & AGE alone & $* *$ & $* *$ & $* *$ & $* *$ & $* *$ & ns & $* *$ \\
\hline & VB2+AGE & $* *$ & $* *$ & $* *$ & $* *$ & $* *$ & $* *$ & $* *$ \\
\hline & VB3+AGE & $* *$ & $* *$ & $* *$ & $* *$ & $* *$ & $* *$ & $* *$ \\
\hline \multirow[t]{2}{*}{ AGE alone vs } & VB2+AGE & $* *$ & $* *$ & $* *$ & $* *$ & $* *$ & $* *$ & $* *$ \\
\hline & VB3+AGE & $* *$ & $* *$ & $* *$ & $* *$ & $* *$ & $* *$ & $* *$ \\
\hline
\end{tabular}

Figure 2. Effects of VBs on the mRNA expression of AGE receptors in NHDF treated with AGE. NHDF were incubated with $10 \mu \mathrm{g} / \mathrm{mL}$ of VB2 or VB3 in the presence or absence of $100 \mu \mathrm{g} / \mathrm{mL}$ AGE. Four hours after the incubation, the mRNA expression levels of AGE receptors were measured by qRT-PCR. The effects of VBs on AGE receptor mRNA expression were examined for significant differences from the untreated group. The effects of VBs on the mRNA expression of AGE receptors under AGE-induced stress conditions were analyzed in comparison with the response of AGE-treated cells alone. ${ }^{* *} p<0.001$.

\subsubsection{Expression of Hsp mRNAs}

We investigated the abilities of VB2 and VB3 to induce the expression of Hsp mRNAs in AGE-treated NHDF. No changes were observed in the mRNA levels of various Hsp when VB2 or VB3 was added alone. However, the mRNA levels of all Hsps, except for Hsp90, were significantly increased by the addition of AGE, and this response was markedly augmented by the additional treatment with VB2 and VB3 (Figure 3). 


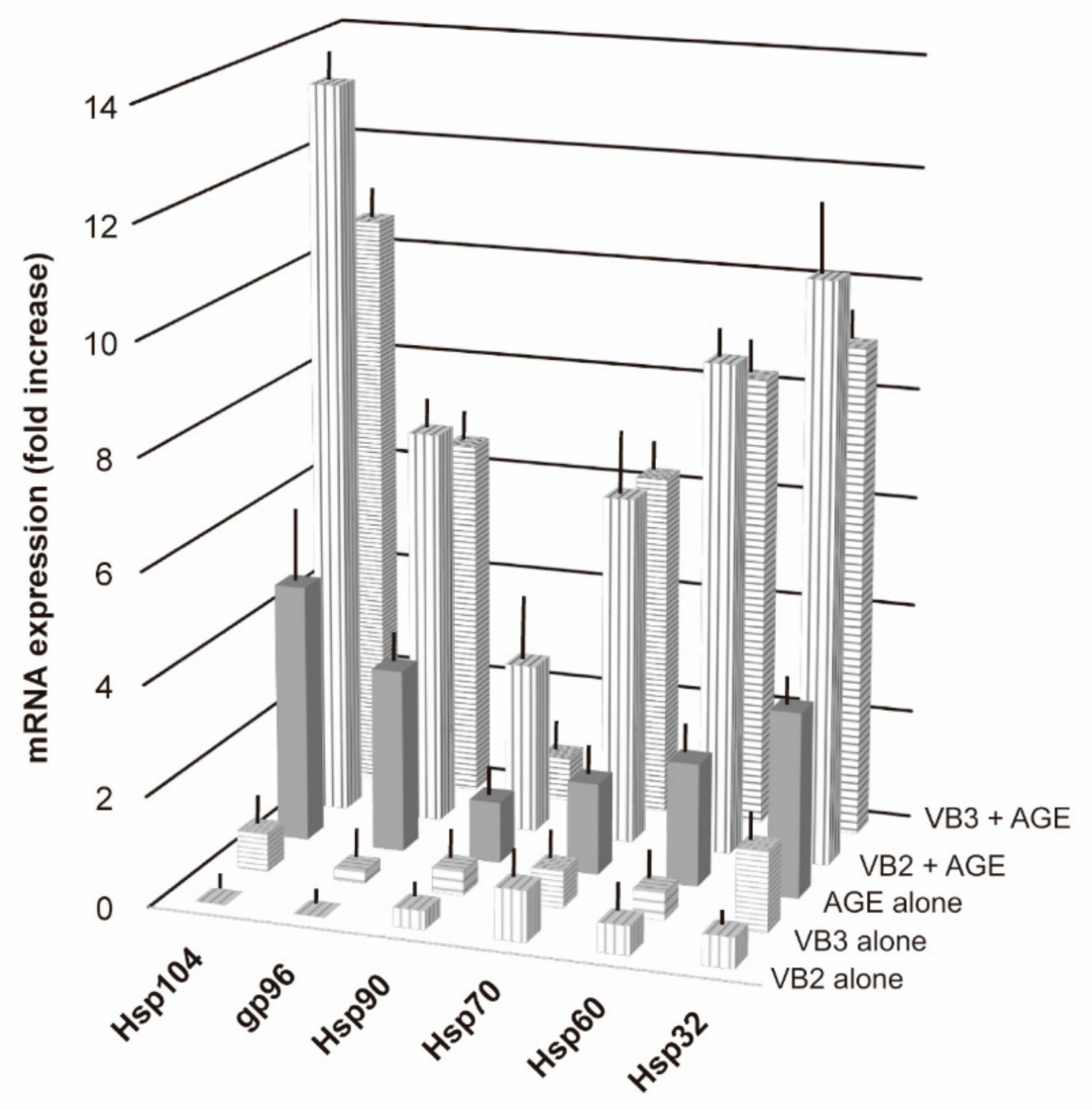

\begin{tabular}{|c|l|c|c|c|c|c|c|}
\hline \multicolumn{2}{|c|}{ t-test } & Hsp104 & gp96 & Hsp90 & Hsp70 & Hsp60 & Hsp32 \\
\hline \multirow{4}{*}{ Control vs } & VB2 alone & $\mathrm{ns}$ & $\mathrm{ns}$ & $\mathrm{ns}$ & $* *$ & $\mathrm{~ns}$ & $\mathrm{~ns}$ \\
\cline { 2 - 8 } & VB3 alone & $\mathrm{ns}$ & $\mathrm{ns}$ & $\mathrm{ns}$ & $\mathrm{ns}$ & $\mathrm{ns}$ & $* *$ \\
\cline { 2 - 8 } & AGE alone & $* *$ & $* *$ & $* *$ & $* *$ & $* *$ & $* *$ \\
\cline { 2 - 8 } & VB2+AGE & $* *$ & $* *$ & $* *$ & $* *$ & $* *$ & $* *$ \\
\cline { 2 - 8 } & VB3+AGE & $* *$ & $* *$ & $* *$ & $* *$ & $* *$ & $* *$ \\
\hline \multirow{5}{*}{ AGE alone vs } & VB2+AGE & $* *$ & $* *$ & $* *$ & $* *$ & $* *$ & $* *$ \\
\cline { 2 - 8 } & VB3+AGE & $* *$ & $* *$ & $\mathrm{~ns}$ & $* *$ & $* *$ & $* *$ \\
\hline
\end{tabular}

ns: not significant, ${ }^{\star \star} p<0.001$

Figure 3. Effects of VBs on the mRNA expression of several heat shock proteins (Hsps) in NHDF treated with AGE. NHDF were incubated with $10 \mu \mathrm{g} / \mathrm{mL}$ of VB2 or VB3 in the presence or absence of $100 \mu \mathrm{g} / \mathrm{mL}$ AGE. Four hours after the incubation, the mRNA expression levels of Hsps were measured using qRT-PCR. The effects of VBs on Hsp mRNA expression levels were examined for significant differences from the untreated group. The effects of VBs on the mRNA expression of Hsps under AGE-induced stress conditions were analyzed in comparison with the response of AGE-treated cells alone. ${ }^{* *} p<0.001$.

\subsection{Effects of VBs on Cell Viability under Oxidative Stress Conditions}

In subsequent experiments, we examined whether VBs ameliorated the response of NHDF to oxidative stress. When NHDF were exposed to oxidative stress with $0.2 \mathrm{mM}$ $\mathrm{H}_{2} \mathrm{O}_{2}$, the cell survival rate decreased to $59 \%$. When VB2 or VB3 was added to these cells under the same stress conditions, the cell survival rate significantly recovered in a VB concentration-dependent manner. Regarding the treatments with VBs, the survival rate increased to $76 \%$ with VB2 at $300 \mu \mathrm{g} / \mathrm{mL}$ and $78 \%$ with VB3 at $300 \mu \mathrm{g} / \mathrm{mL}$. In addition, when NHDF were exposed to oxidative stress after the treatment with VB2 or VB3, cells were more likely to become resistant to oxidative stress. This induced resistance was 
completely dependent on the concentration of VBs and a significant increase in cell viability was observed in cells treated with VB2 and VB3 at concentrations as low as $10 \mu \mathrm{g} / \mathrm{mL}$ (Figure 4).

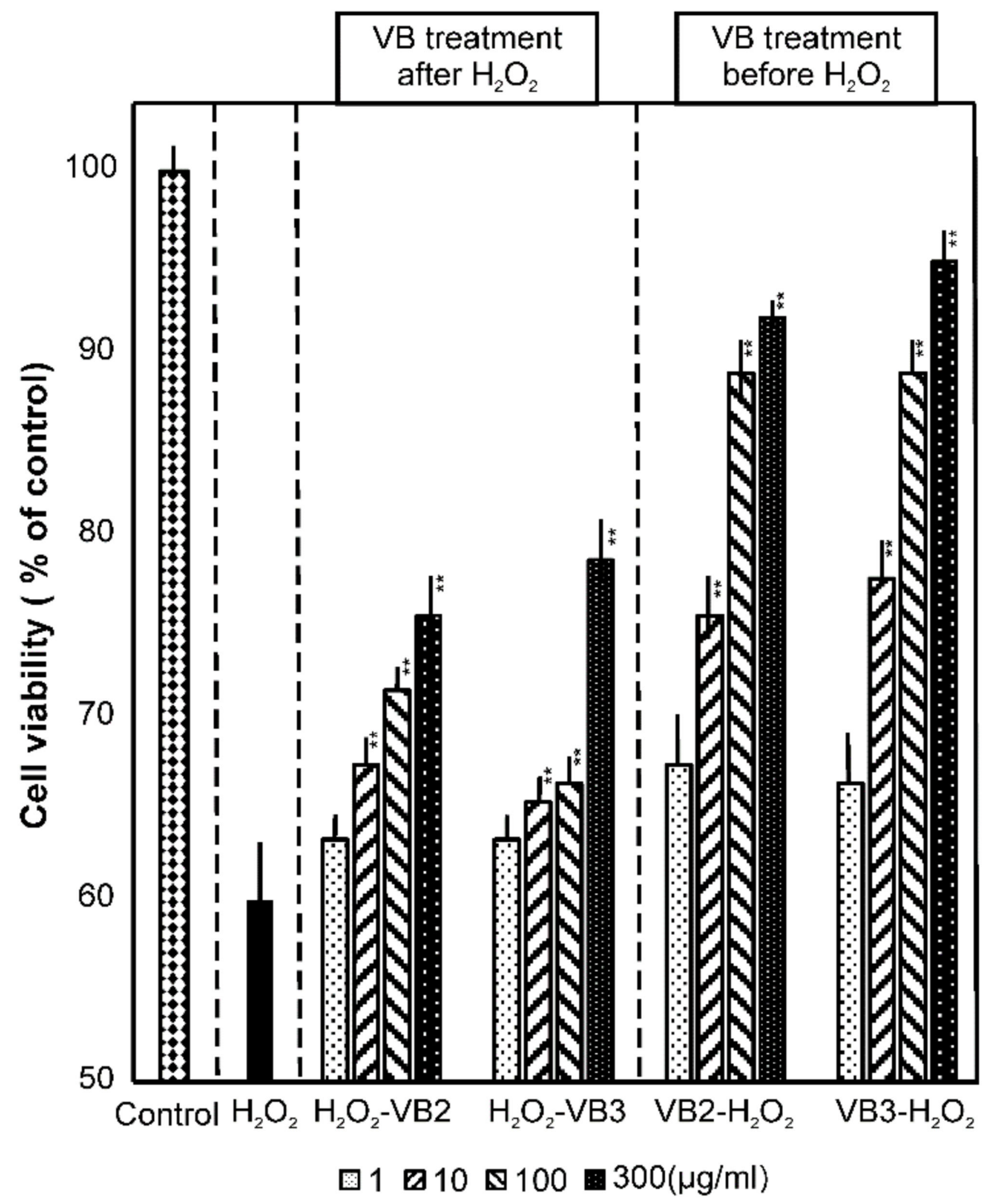

Figure 4. Protective effects of VB2 and VB3 on the viability of NHDF treated with $\mathrm{H}_{2} \mathrm{O}_{2}$. NHDF were treated with VBs in the presence of $\mathrm{H}_{2} \mathrm{O}_{2}$ as described in the Materials and Methods. Cells were cultured for another $18 \mathrm{~h}$ and viability was measured. The significance of differences in the effects of VBs on cell viability was analyzed in comparison with that in the $\mathrm{H}_{2} \mathrm{O}_{2}$-treated group. ${ }^{* *} p<0.001$.

\subsection{Effects of VBs on the Production of Intracellular ROS and SOD}

To investigate the effects of VBs as anti-aging agents, the impact of VBs on oxidative stress-induced intracellular ROS production was evaluated using fluorescent DCF-DA as an indicator (Figure 5a). The intensity of fluorescence increased in cells exposed to $\mathrm{H}_{2} \mathrm{O}_{2}$ by 3.7-fold from normal cells. When cells were treated with VBs after being exposed to $\mathrm{H}_{2} \mathrm{O}_{2}$, intracellular ROS production was significantly suppressed by the treatments with VBs in a concentration-dependent manner. Furthermore, $\mathrm{H}_{2} \mathrm{O}_{2}$-induced ROS levels were markedly suppressed by the previous treatment of cells with VBs. 


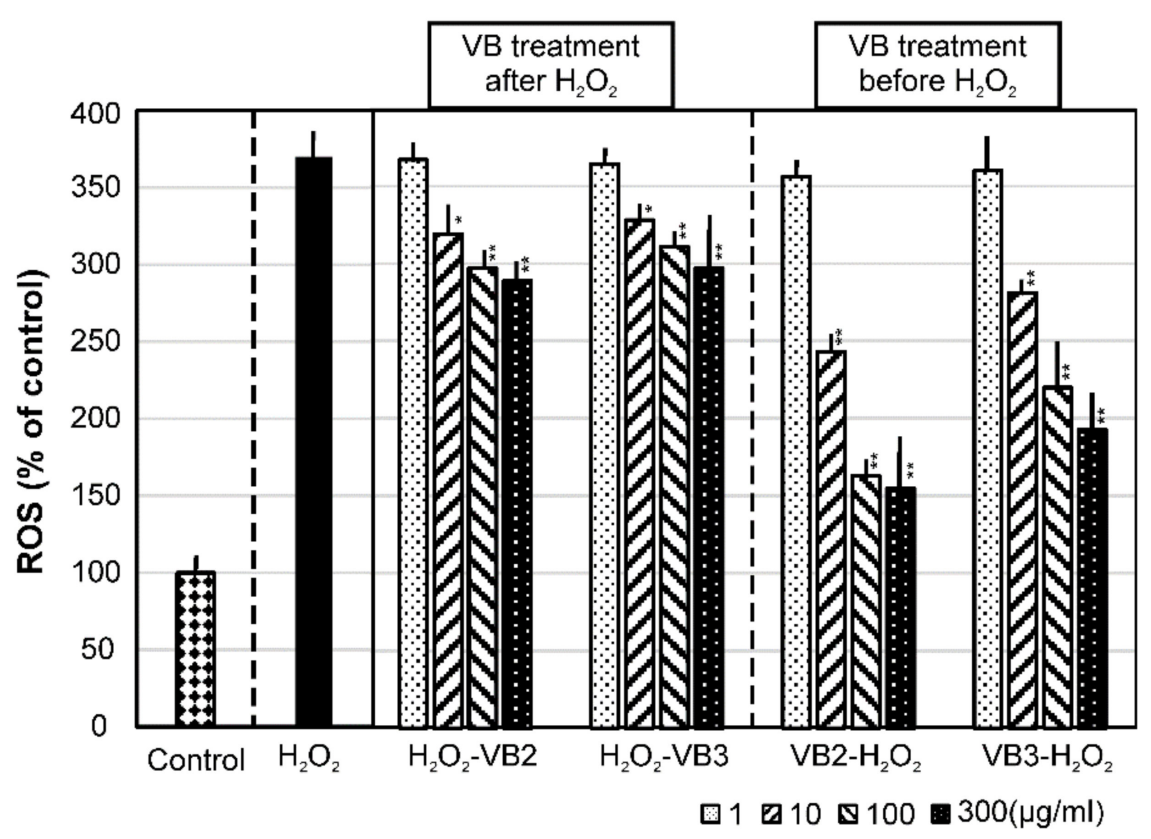

(a)

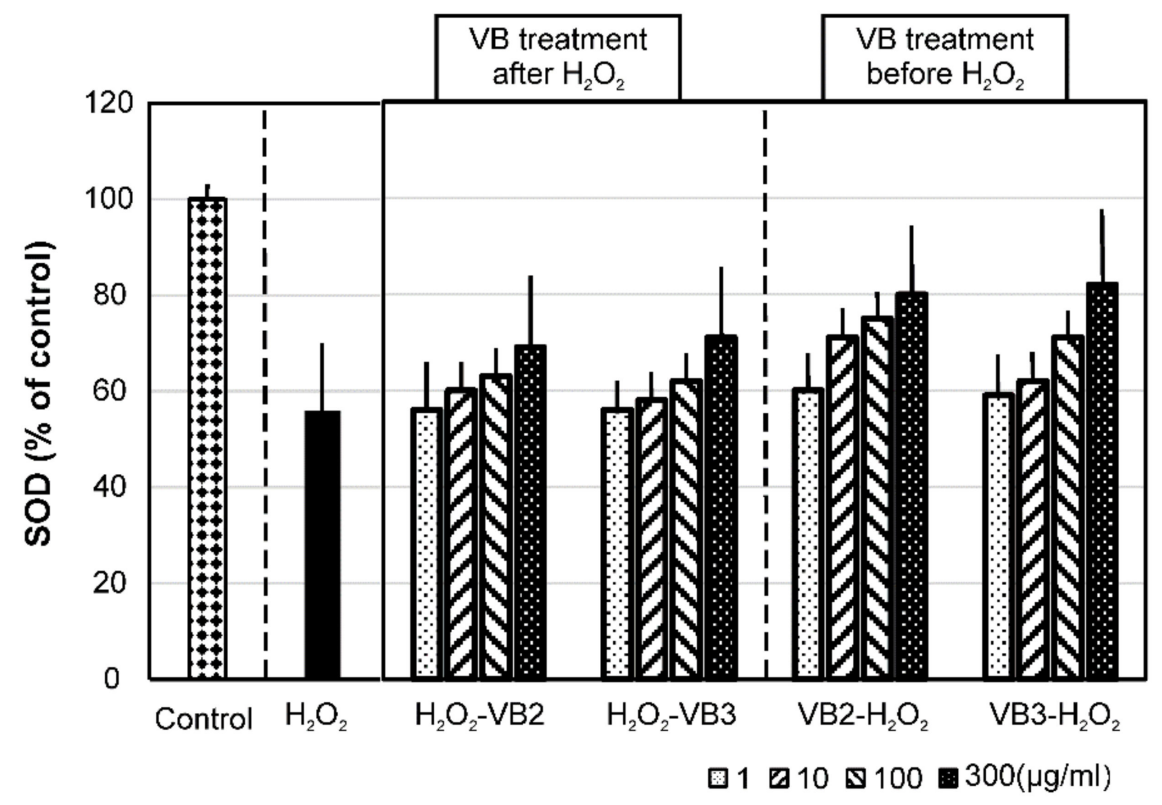

(b)

Figure 5. Effects of VBs on the generation of ROS and SOD in NHDF treated with $\mathrm{H}_{2} \mathrm{O}_{2}$. To evaluate the therapeutic effects of VBs on oxidative stress, NHDF were treated with $0.2 \mathrm{mM} \mathrm{H}_{2} \mathrm{O}_{2}$ for $2 \mathrm{~h}$, washed with PBS, and continued to be cultured with VBs for $4 \mathrm{~h}$. In another experiment, cells were initially treated with VBs for $4 \mathrm{~h}$, washed, and then cultured with $0.2 \mathrm{mM} \mathrm{H}_{2} \mathrm{O}_{2}$ for $2 \mathrm{~h}$ to monitor prophylactic effects. The level of ROS generated in cells was measured using DCF-DA as described in the Materials and Methods (a). In addition, the level of intracellular SOD was quantitated and expressed as a percentage of that in the control (b). ${ }^{*} p<0.01,{ }^{* *} p<0.001$.

In contrast to ROS production, SOD levels decreased to $56 \%$ of the control following an exposure to $\mathrm{H}_{2} \mathrm{O}_{2}$ and recovered with the VB treatments in a concentration-dependent manner. Furthermore, a previous treatment with VBs appeared to confer resistance to $\mathrm{H}_{2} \mathrm{O}_{2}$-induced reductions in the production of SOD (Figure 5b). 
3.4. Effects of VBs on the mRNA Expression of $A Q P-1$ and $A Q P-3$ and on the Production of Hyaluronan and Elastin under Oxidative Stress Conditions

Figure 6a,b show the mRNA levels of AQP-1 and AQP-3, which are cell surface molecules that contribute to skin moisturization. The mRNA expression of AQP- 1 and AQP-3 markedly decreased when NHDF were exposed to $\mathrm{H}_{2} \mathrm{O}_{2}$, but was recovered by the $\mathrm{VB}$ treatments in a concentration-dependent manner after oxidative stress. The previous treatment of cells with VBs conferred resistance to $\mathrm{H}_{2} \mathrm{O}_{2}$-induced reductions in mRNA expression levels. The effects of VBs in cells were observed at concentrations of $1 \mu \mathrm{g} / \mathrm{mL}$ and higher, and no significant differences were noted between VB2 and VB3.

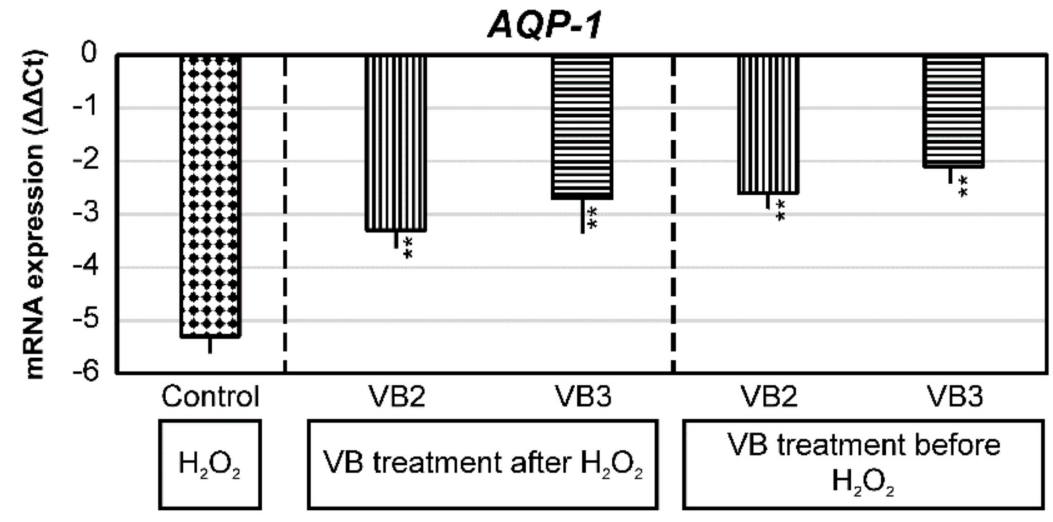

(a)

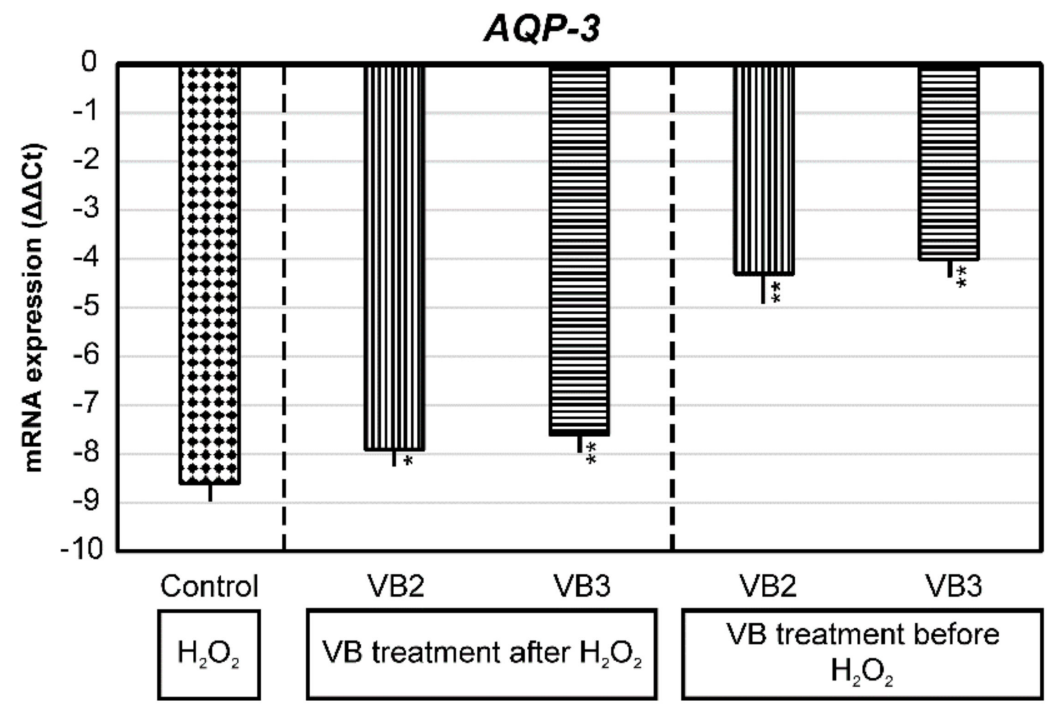

(b)

Figure 6. Effects of VBs on the mRNA expression of aquaporins in NHDF treated with $\mathrm{H}_{2} \mathrm{O}_{2}$. To evaluate the therapeutic effects of VBs on oxidative stress, NHDF were treated with $0.2 \mathrm{mM} \mathrm{H}_{2} \mathrm{O}_{2}$ for $2 \mathrm{~h}$, washed with PBS, and continued to be cultured with $10 \mu \mathrm{g} / \mathrm{mL}$ VBs for $4 \mathrm{~h}$. In another experiment, cells were initially treated with $10 \mu \mathrm{g} / \mathrm{mL}$ VBs for $4 \mathrm{~h}$, washed, and then cultured with $0.2 \mathrm{mM} \mathrm{H}_{2} \mathrm{O}_{2}$ for $2 \mathrm{~h}$ to monitor prophylactic effects. The mRNA expression levels of aquaporin1 (AQP-1) and aquaporin-3 (AQP-3) were measured by qRT-PCR. mRNA expression levels were expressed as $\Delta \Delta$ Ct. (a): AQP-1 mRNA levels, (b): AQP-3 mRNA levels. ${ }^{*} p<0.01,{ }^{* *} p<0.001$.

Figure $7 \mathrm{a}, \mathrm{b}$ show the amount of hyaluronan secreted in the culture supernatant and the amount of intracellular elastin. The level of hyaluronan decreased to approximately $50 \%$ that of the control after the $\mathrm{H}_{2} \mathrm{O}_{2}$ treatment and this reduction was not recovered by the VB treatments. On the other hand, $\mathrm{H}_{2} \mathrm{O}_{2}$-induced reductions in hyaluronan production appeared to be minimized by the previous treatment of cells with VBs at higher concentrations (Figure 7a). 


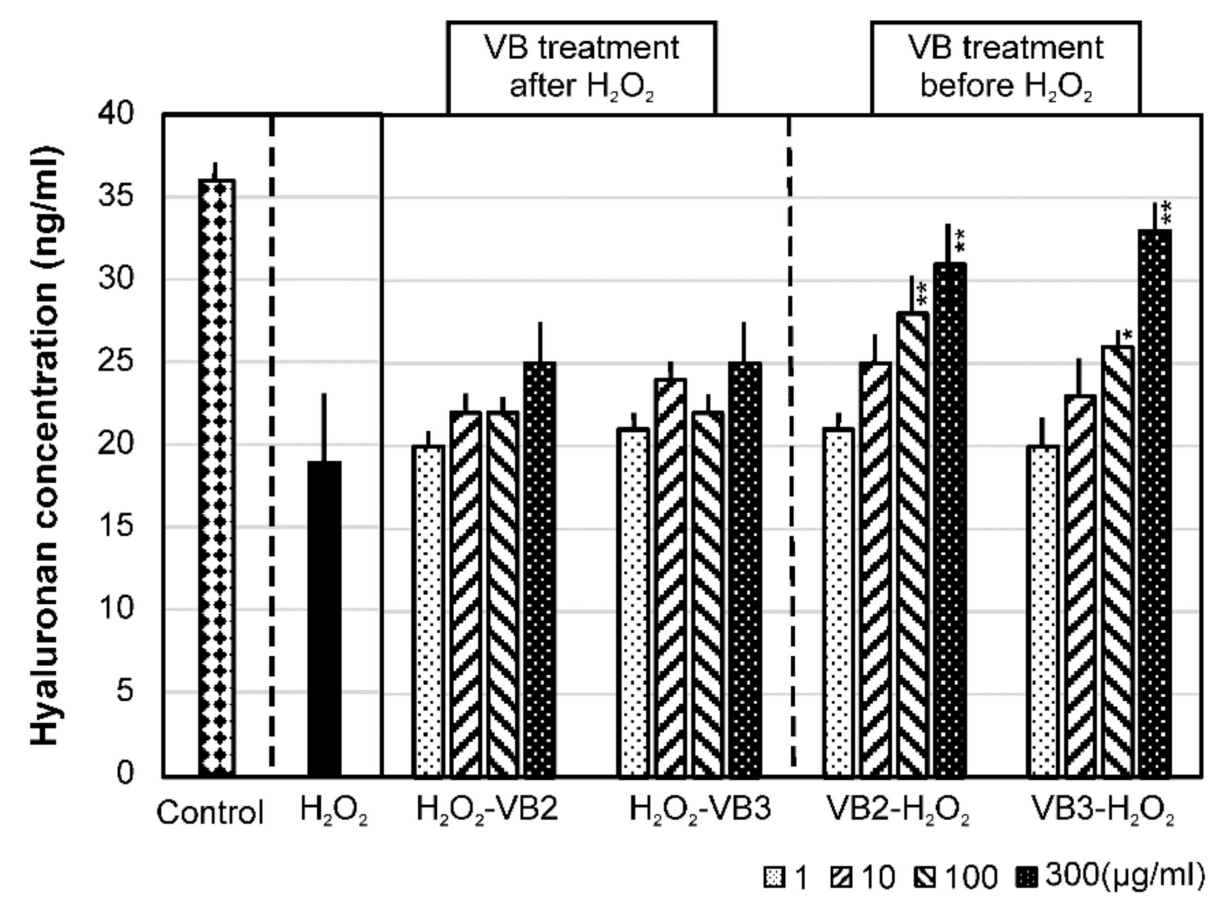

(a)

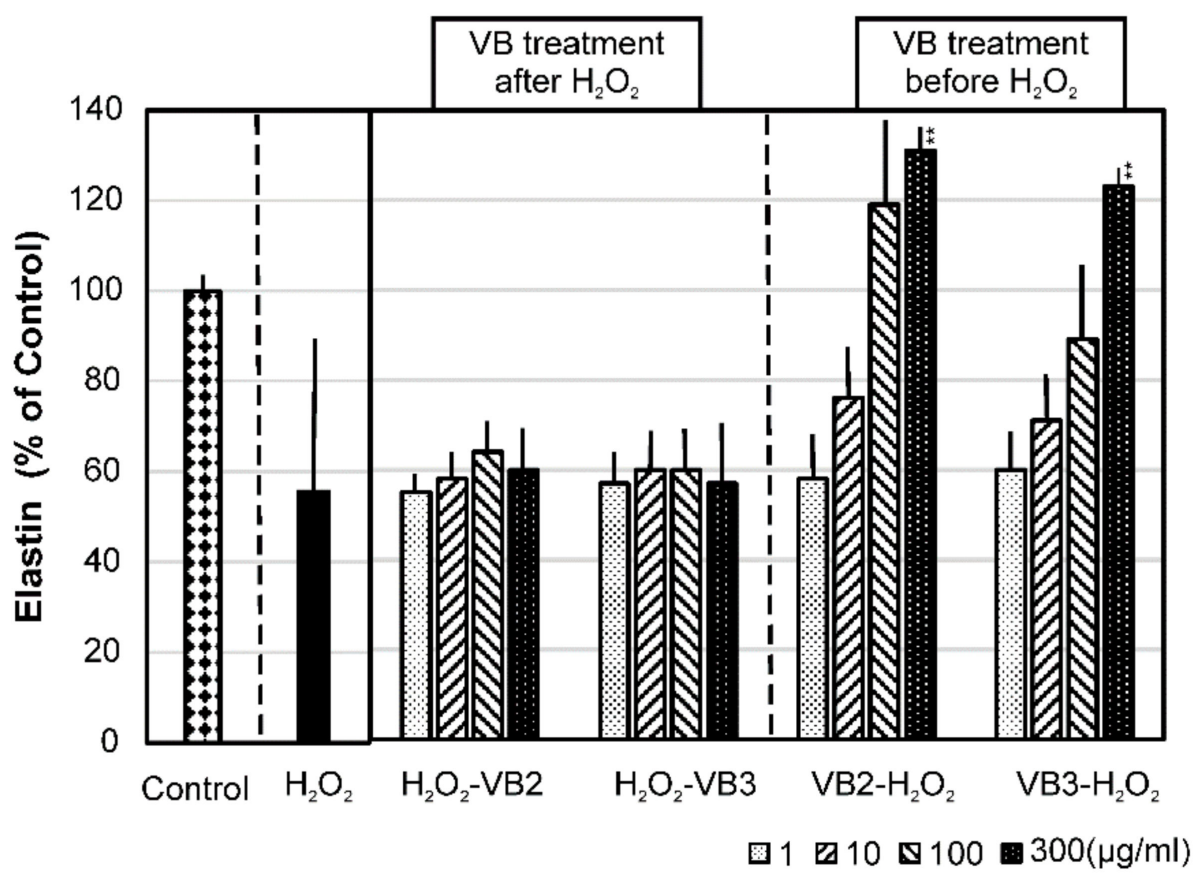

(b)

Figure 7. Effects of VBs on the production of hyaluronan and elastin in NHDF treated with $\mathrm{H}_{2} \mathrm{O}_{2}$. To evaluate the therapeutic effects of VBs on oxidative stress, NHDF were treated with $0.2 \mathrm{mM} \mathrm{H}_{2} \mathrm{O}_{2}$ for $2 \mathrm{~h}$, washed with PBS, and continued to be cultured with various concentrations of VBs for $4 \mathrm{~h}$. In another experiment, cells were initially treated with various concentrations of VBs for $4 \mathrm{~h}$, washed, and then cultured with $0.2 \mathrm{mM} \mathrm{H}_{2} \mathrm{O}_{2}$ for $2 \mathrm{~h}$ to monitor prophylactic effects. (a); Following the treatments with $\mathrm{VBs}$ and $\mathrm{H}_{2} \mathrm{O}_{2}$, the concentration of hyaluronan in the culture supernatant was measured. (b); VB- and $\mathrm{H}_{2} \mathrm{O}_{2}$-treated cells were lysed in lysis buffer and the amount of elastin was measured. Data were expressed as a percentage of that in the control. ${ }^{*} p<0.01,{ }^{* *} p<0.001$. 
Similar to hyaluronan, the production of elastin decreased to $56 \%$ that of the control after the $\mathrm{H}_{2} \mathrm{O}_{2}$ treatment. This reduction was not recovered by the VB treatments. On the other hand, $\mathrm{H}_{2} \mathrm{O}_{2}$-induced reductions in elastin production appeared to mostly be cancelled by the previous treatment of cells with VBs at higher concentrations. Elastin production increased to levels above the control when cells were treated with VB2 at $100 \mu \mathrm{g} / \mathrm{mL}$ or higher and VB3 at $300 \mu \mathrm{g} / \mathrm{mL}$ (Figure $7 \mathrm{~b}$ ).

\section{Discussion}

We previously reported that VBs are very stable molecules that exhibit strong antiviral and anti-bacterial activities [19]. In addition to those findings, VBs are characterized by their extremely low cytotoxicity. In fact, it has been found that they do not exert any cytotoxicity even when cells are treated with concentrations 3000 times higher than those used in this study. To investigate the versatility of 2 PMs (VB2 and VB3), we herein focused on their anti-aging effects on skin as well as their ability to induce cytoprotective responses in NHDF exposed to AGE and $\mathrm{H}_{2} \mathrm{O}_{2}$. The results obtained clearly demonstrated that the addition of VBs to normal cutaneous fibroblasts alone did not induce marked changes in cells, but up-regulated the expression of cytoprotective molecules and ameliorated adverse responses in cells exposed to stress. Specifically, neither VB2 nor VB3 affected the mRNA expression of AGE receptors or Hsps in NHDF when used alone (Figures 2 and 3). In NHDF exposed to AGE, VB2 and VB3 markedly increased the transcription of AGE receptors, particularly FEEL-1, FEEL-2, and RAGE. A previous study reported that FEEL-1 and FEEL-2 played a role in cytoprotection by participating in the endocytosis of free AGEs in cells and their degradation by lysosomes [29]. On the other hand, RAGE is known to contribute to the generation of ROS by activating NADPH oxidase. The enhanced transcription of RAGE may be linked to increased ROS production. In the case of RAGE, splice mutations occur during transcription, resulting in two variants; one is RAGE that lacks intracellular domains (C-terminally truncated RAGE: C-RAGE), which is a soluble RAGE protein released from cells, and the other is RAGE that lacks an extracellular V domain (N-terminally truncated RAGE: N-RAGE) [30,31]. Because these two truncated RAGE did not exert any function as AGE receptors, the increased transcription of RAGE may not necessarily promote the production of ROS. This issue warrants further study.

We then examined the effects of VBs on the mRNA expression of Hsps. The expression of Hsps is generally up-regulated by environmental stress, such as heat, ultraviolet light, and ROS. Hsps perform chaperone functions by stabilizing newly synthesized proteins to ensure correct folding or by helping to refold proteins damaged by stress. Hsp104 has been shown to mediate the disaggregation of proteins [32] and gp96 is involved in intracellular antigen presentation [33]. Hsp90 assists proteins to fold properly and remain stable when exposed to stress and facilitates the maturation of strictly selected proteins [34]. Hsp70 has been shown to regulate the quality of proteins by controlling their folding, transport, and degradation $[35,36]$. Hsp60 maintains the folding of proteins in mitochondria and is involved in the membrane penetration of proteins in mitochondria [37]. Hsp32 is involved in heme degradation, the products of which exhibit antioxidant activities [38]. Because VB2 and VB3 are both capable of similarly inducing the expression of Hsps in cells subjected to AGE stress, VBs appear to function as potent cytoprotecting agents under stress conditions.

In an experiment to investigate the response of cells exposed to $\mathrm{H}_{2} \mathrm{O}_{2}$, we observed an approximately $40 \%$ reduction in cell viability. In contrast, the VB treatments markedly increased cell viability in a concentration-dependent manner. Furthermore, the response of cells treated with VBs and then incubated with $\mathrm{H}_{2} \mathrm{O}_{2}$ (the prophylactic effects of VBs) was stronger than that of cells incubated with $\mathrm{H}_{2} \mathrm{O}_{2}$ prior to the VB treatments (the therapeutic effects of VBs; Figure 4). To elucidate the underlying mechanisms, we assessed intracellular ROS and SOD production levels. Intracellular ROS levels were markedly increased by the $\mathrm{H}_{2} \mathrm{O}_{2}$ treatment, but suppressed by VB2 and VB3 in a concentration-dependent manner. This prophylactic effect of VBs on ROS production was also stronger than its therapeutic effect (Figure 5a). On the other hand, the production of SOD, a potent scavenger of 
ROS, was significantly decreased by the $\mathrm{H}_{2} \mathrm{O}_{2}$ treatment; the amount of SOD was slightly ameliorated by the VB treatments (Figure 5b). Therefore, $\mathrm{H}_{2} \mathrm{O}_{2}$-induced cell death appears to be related to increases in intracellular ROS levels. Because SOD production levels were not markedly affected by VBs, the decrease observed in ROS production after the VB treatments may be due to an inhibitory effect on the cellular response to ROS generation. So far, the DCF-DA used in this study is a versatile probe for ROS detection and has no specificity, so it has not been clarified which of the ROS species is suppressed by treatment with VBs, or whether the production of every ROS species is suppressed by VBs. This issue warrants further clarification.

Fibroblasts have been shown to play a role in epidermal moisturization, and the functional role of AQP, particularly AQP-1 and AQP-3, which are expressed in fibroblasts and involved in the influx of water molecules into cells, is attracting increasing attention. Moreover, hyaluronan secreted from cells has been implicated in skin moisturization [39]. In the present study, the mRNA expression of AQP-1 and AQP-3 and secretion of hyaluronan were both reduced by oxidative stress (Figures $6 a, b$ and $7 a$ ), but were recovered in cells treated with VB2 or VB3. Similar to the previous results, VB-induced ameliorating effects on oxidative stress were more effective when they acted prophylactically (Figure 7a,b). In humans, 50\% of hyaluronan is present in skin [40]. Hyaluronan decreases in the epidermis with aging, whereas it is retained in the dermis. This alteration contributes to the loss of moisture, a decrease in elasticity, and the shrinkage of skin [40]. Moreover, oxidative stress has been shown to decrease collagen and elastin, which is followed by the formation of wrinkles and a decline in skin regeneration [41]. In the present study, the prophylactic use of VBs suppressed reductions in hyaluronan and elastin under oxidative stress conditions, suggesting the potential of VB2 and VB3 as anti-aging agents and their prophylactic use to exert anti-aging activity. So far, we have demonstrated the effects of VB on human fibroblasts under stress conditions, but to clarify the exact anti-aging effects of VB on skin, it will be necessary to determine the effect of VB on keratinocytes and conduct in vivo experiments. We try to work on these issues at an early stage and clarify the effects of VB. Furthermore, if the beneficial mechanisms of VBs become clear, we attempt to apply VBs to hygiene products and cosmetics to develop high-value products that contribute more to society.

\section{Conclusions}

The effects of VBs based on the present results are summarized in Figure 8. No changes were observed in various parameters when cells were treated with VB2 or VB3 alone. However, under stress conditions caused by AGE and $\mathrm{H}_{2} \mathrm{O}_{2}$, intracellular ROS production was augmented. VB2 and VB3 preferentially induced the expression of cytoprotecting molecules and suppressed ROS production, which may eventually cause serious illnesses, such as arteriosclerosis and cancer, as well as aging-related phenomena. VB2 and VB3 are compounds that both exhibit strong anti-viral and anti-bacterial activities. The present results suggest the potential of VB2 and VB3 as anti-aging agents for skin.

In a normal environment without stress, antioxidants produced homeostatically remove ROS. On the other hand, ROS production increases under stress conditions induced by $\mathrm{AGE}$ and $\mathrm{H}_{2} \mathrm{O}_{2}$, which may lead to aging, inflammation, and atherosclerosis. VBs appear to have the ability to promote the production of antioxidants under stress conditions and enhance the stress response of cells. 


\section{Normal condition with VB2 and VB3}

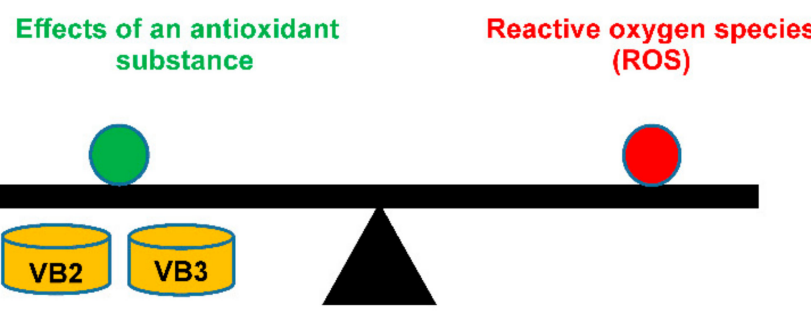

(a)

Oxidative stress condition without VB2 and VB3

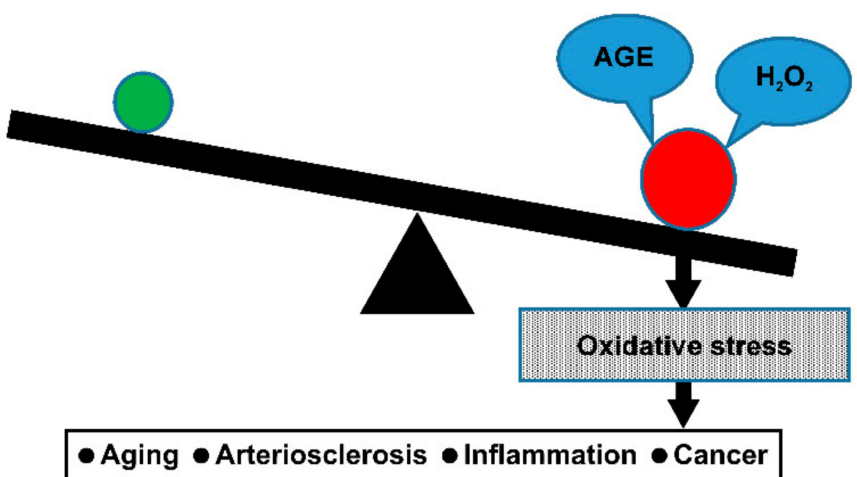

(b)

Oxidative stress condition with VB2 and VB3

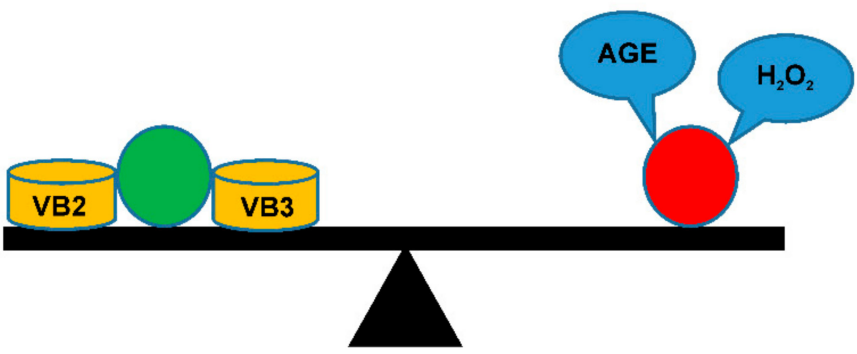

(c)

Figure 8. Importance of the balance between oxidative stress and antioxidant effects. There is little effect on the cells when VBs are applied in a stress-free condition (a). On the other hand, under AGE- and $\mathrm{H}_{2} \mathrm{O}_{2}$-induced stress conditions, intracellular ROS production is increased. Such oxidative stress can lead to aging, atherosclerosis, inflammation, and cancer (b). However, in such a stressful environment, VBs induce the expression of molecules that exert cytoprotective effects and suppress ROS production (c).

Author Contributions: Conceptualization: K.F.; K.D.; T.T.-K. and I.K.; Investigation and Formal Analysis: K.D. and K.F.; Methodology and Data Interpretation: all authors; Writing-Original Draft Preparation: K.F. and K.D. All authors have read and agreed to the published version of the manuscript.

Funding: This research received no external funding.

Institutional Review Board Statement: Not applicable.

Informed Consent Statement: Not applicable.

Acknowledgments: The authors express their sincere gratitude to Toshihiro Yamase, who laid the foundation for research on polyoxometalates and for granting the right to use some of the compounds. 
They are also grateful to FSX Company and those engaged in VB-compounded hygienic products for their generous cooperation.

Conflicts of Interest: The authors declare no conflict of interest.

\section{References}

1. Babior, B.M. Phagocytes and oxidative stress. Am. J. Med. 2000, 109, 33-44. [CrossRef]

2. Ben-Porath, I.; Weinberg, R. A The signals and pathways activating cellular senescence. Int. J. Biochem. Cell Biol. 2005, 37, 961-976. [CrossRef] [PubMed]

3. Richter, T.; von Zglinicki, T. A continuous correlation between oxidative stress and telomere shortening in fibroblasts. Exp. Gerontol. 2007, 42, 1039-1042. [CrossRef]

4. Mizutani, H.; Tada-Oikawa, S.; Hiraku, Y.; Oikawa, S.; Kojima, M.; Kawanishi, S. Mechanism of apoptosis induced by a new topoisomerase inhibitor through the generation of hydrogen peroxide. J. Biol. Chem. 2002, 277, 30684-30689. [CrossRef]

5. $\quad$ Brunet, A.; Sweeney, L.B.; Sturgill, J.F.; Chua, K.F.; Greer, P.L.; Lin, Y.; Tran, H.; Ross, S.E.; Mostoslavsky, R.; Cohen, H.Y.; et al. Stress-dependent regulation of FOXO transcription factors by the SIRT1 deacetylase. Science 2004, 303, 2011-2015. [CrossRef] [PubMed]

6. Yagi, M.; Yonei, Y. Glycative Stress and Anti-Aging: 7. Glycative stress and skin aging. Glycative Stress Res. 2018, 5, 50-54.

7. Saxena, S.; Vekaria, H.; Sullivan, P.G.; Seifert, A.W. Connective tissue fibroblasts from highly regenerative mammals are refractory to ROS-induced cellular senescence. Nat. Commun. 2019, 10, 4400. [CrossRef]

8. Reiser, K.M. Nonenzymatic glycation of collagen in aging and diabetes. Proc. Soc. Exp. Biol. Med. 1998, 218, 23-37. [CrossRef]

9. Reddy, V.P.; Obrenovich, M.E.; Atwood, C.S.; Perry, G.; Smith, M.A. Involvement of Maillard reactions in Alzheimer disease. Neurotox. Res. 2002, 4, 191-209. [CrossRef]

10. Schram, M.T.; Schalkwijk, C.G.; Bootsma, A.H.; Fuller, J.H.; Chaturvedi, N.; Stehouwer, C.D.; EURODIAB Prospective Complications Study Group. Advanced glycation end products are associated with pulse pressure in type 1 diabetes: The EURODIAB Prospective Complications Study. Hypertension 2005, 46, 232-237. [CrossRef]

11. Brownlee, M.; Vlassara, H.; Kooney, A.; Ulrich, P.; Cerami, A. Aminoguanidine prevents diabetes-induced arterial wall protein cross-linking. Science 1986, 232, 1629-1632. [CrossRef] [PubMed]

12. Saito, M.; Fujii, K.; Soshi, S.; Tanaka, T. Reductions in degree of mineralization and enzymatic collagen cross-links and increases in glycation-induced pentosidine in the femoral neck cortex in cases of femoral neck fracture. Osteoporos. Int. 2006, 17, 986-995. [CrossRef]

13. Kawanishi, S.; Hiraku, Y.; Oikawa, S. Mechanism of guanine-specific DNA damage by oxidative stress and its role in carcinogenesis and aging. Mutat. Res. 2001, 488, 65-76. [CrossRef]

14. Wang, Y.; Branicky, R.; Noë, A.; Hekimi, S. Superoxide dismutases: Dual roles in controlling ROS damage and regulating ROS signaling. J. Cell Biol. 2018, 217, 1915-1928. [CrossRef]

15. Xu, Y.; Yao, H.; Wang, Q.; Xu, W.; Liu, K.; Zhang, J.; Zhao, H.; Hou, G. Aquaporin-3 Attenuates oxidative stress-induced nucleus pulposus cell apoptosis through regulating the P38 MAPK pathway. Cell. Physiol. Biochem. 2018, 50, 1687-1697. [CrossRef]

16. Quan, T.; Qin, Z.; Xia, W.; Shao, Y.; Voorhees, J.J.; Fisher, G.J. Matrix-degrading metalloproteinases in photoaging. J. Investig. Dermatol. Symp. Proc. 2009, 14, 20-24. [CrossRef]

17. Xu, Q.; Hou, W.; Zheng, Y.; Liu, C.; Gong, Z.; Lu, C.; Lai, W.; Maibach, H.I. Ultraviolet A-induced cathepsin K expression is mediated via MAPK/AP-1 pathway in human dermal fibroblasts. PLoS ONE 2014, 9, e102732. [CrossRef]

18. Yamase, T. Polyoxometalates active against tumors, viruses, and bacteria Review. Prog. Mol. Subcell. Biol. 2013, 54, 65-116. [CrossRef] [PubMed]

19. Dan, K.; Miyashita, K.; Seto, Y.; Fujita, H.; Yamase, T. Mechanism of the protective effect of heteropolyoxotungstate against herpes simplex virus type 2. Pharmacology 2003, 67, 83-89. [CrossRef] [PubMed]

20. Dan, K.; Fujinami, K.; Sumitomo, H.; Ogiwara, Y.; Suhara, S.; Konno, Y.; Sawada, M.; Soga, Y.; Takada, A.; Takanashi, K.; et al. Application of antiviral polyoxometalates to living environments-Antiviral moist hand towels and stationery items. Appl. Sci. 2020, 10, 8246. [CrossRef]

21. Maeda, S.; Matsui, T.; Ojima, A.; Takeuchi, M.; Yamagishi, S. Sulforaphane inhibits advanced glycation end product-induced pericyte damage by reducing expression of receptor for advanced glycation end products. Nutr. Res. 2014, 34, 807-813. [CrossRef] [PubMed]

22. Kartal, B.; Akçay, A.; Palabiyik, B. Oxidative stress upregulates the transcription of genes involved in thiamine metabolism. Turk. J. Biol. 2018, 42, 447-452. [CrossRef] [PubMed]

23. Chen, Y.H.; Chen, Z.W.; Li, H.M.; Yan, X.F.; Feng, B. AGE/RAGE-induced EMP release via the NOX-derived ROS pathway. J. Diabetes Res. 2018, 2018, 6823058. [CrossRef]

24. Stoll, S.J.; Bartsch, S.; Kroll, J. HOXC9 regulates formation of parachordal lymphangioplasts and the thoracic duct in zebrafish via stabilin 2. PLoS ONE 2013, 8, e58311. [CrossRef]

25. Draude, G.; Lorenz, R.L. TGF-beta1 downregulates CD36 and scavenger receptor A but upregulates LOX-1 in human macrophages. Am. J. Physiol. Heart Circ. Physiol. 2000, 278, H1042-H1048. [CrossRef] [PubMed]

26. Yamada, Y.; Ishibashi, K.; Ishibashi, K.; Bhutto, I.A.; Tian, J.; Lutty, G.A.; Handa, J.T. The expression of advanced glycation endproduct receptors in rpe cells associated with basal deposits in human maculas. Exp. Eye Res. 2006, 82, 840-848. [CrossRef] 
27. Casselmann, C.; Reimann, A.; Friedrich, I.; Schubert, A.; Silber, R.E.; Simm, A. Age-dependent expression of advanced glycation end product receptor genes in the human heart. Gerontology 2004, 50, 127-134. [CrossRef] [PubMed]

28. Bründl, J.; Wallinger, S.; Breyer, J.; Weber, F.; Evert, M.; Georgopoulos, N.T.; Rosenhammer, B.; Burger, M.; Otto, W.; Rubenwolf, P. Expression, Localization and potential significance of aquaporins in benign and malignant human prostate tissue. BMC Urol. 2018, 18, 75. [CrossRef]

29. Tamura, Y.; Adachi, H.; Osuga, J.; Ohashi, K.; Yahagi, N.; Sekiya, M.; Okazaki, H.; Tomita, S.; Iizuka, Y.; Shimano, H.; et al. FEEL-1 and FEEL-2 are endocytic receptors for advanced glycation end products. J. Biol. Chem. 2003, 278, 12613-12617. [CrossRef] [PubMed]

30. Koyama, H.; Yamamoto, H.; Nishizawa, Y. RAGE and soluble RAGE: Potential therapeutic targets for cardiovascular diseases. Mol. Med. 2007, 13, 625-635. [CrossRef]

31. Lee, A.C.; Lam, J.K.; Shiu, S.W.; Wong, Y.; Betteridge, D.J.; Tan, K.C. Serum level of soluble receptor for advanced glycation end products is associated with a disintegrin and metalloproteinase 10 in type 1 diabetes. PLoS ONE 2015, 10, e0137330. [CrossRef]

32. Inoue, Y.; Hanazono, Y.; Noi, K.; Kawamoto, A.; Kimatsuka, M.; Harada, R.; Takeda, K.; Kita, R.; Iwamasa, N.; Shibata, K.; et al Split conformation of Chaetomium thermophilum Hsp104 disaggregase. Structure 2021, 29, 721-730.e6. [CrossRef] [PubMed]

33. Udono, H.; Levey, D.L.; Srivastava, P.K. Cellular Requirements for tumor-specific immunity elicited by heat shock proteins: Tumor rejection antigen gp96 primes CD8 ${ }^{+}$T cells in vivo. Proc. Natl. Acad. Sci. USA 1994, 91, 3077-3081. [CrossRef] [PubMed]

34. Pozo, F.M.; Oda, T.; Sekimoto, T.; Murakumo, Y.; Masutani, C.; Hanaoka, F.; Yamashita, T. Molecular chaperone Hsp90 regulates REV1-mediated mutagenesis. Mol. Cell. Biol. 2011, 31, 3396-3409. [CrossRef]

35. Rapoport, I.; Boll, W.; Yu, A.; Böcking, T.; Kirchhausen, T. A motif in the clathrin heavy chain required for the Hsc70/auxilin uncoating reaction. Mol. Biol. Cell 2008, 19, 405-413. [CrossRef]

36. Cuervo, A.M. Chaperone-mediated autophagy: Dice's 'wild' idea about lysosomal selectivity. Nat. Rev. Mol. Cell Biol. 2011, 12, 535-541. [CrossRef] [PubMed]

37. Horwich, A.L. Chaperonin-mediated protein folding. J. Biol. Chem. 2013, 288, 23622-23632. [CrossRef] [PubMed]

38. Barakat, B.M.; Ahmed, H.I.; Bahr, H.I.; Elbahaie, A.M. Protective Effect of Boswellic Acids Against Doxorubicin-induced hepatotoxicity: Impact on Nrf2/HO-1 defense pathway. Oxid. Med. Cell. Longev. 2018, 2018, 8296451. [CrossRef] [PubMed]

39. Sundaram, H.; Cegielska, A.; Wojciechowska, A.; Delobel, P. Prospective, randomized, investigator-blinded, split-face evaluation of a topical crosslinked hyaluronic acid serum for post-procedural improvement of skin quality and biomechanical attributes. J. Drugs Dermatol. 2018, 17, 442-450.

40. Kirkpatrick, C.E.; Megella, C. Use of ivermectin in treatment of Aelurostrongylus abstrusus and Toxocara cati infection in a cat. J. Am. Vet. Med. Assoc. 1987, 190, 1309-1310. [PubMed]

41. Song, I.B.; Gu, H.; Han, H.J.; Lee, N.Y.; Cha, J.Y.; Son, Y.K.; Kwon, J. Effects of 7-MEGA ${ }^{\mathrm{TM}} 500$ on oxidative stress, inflammation, and skin regeneration in $\mathrm{H}_{2} \mathrm{O}_{2}$-treated skin cells. Toxicol. Res. 2018, 34, 103-110. [CrossRef] [PubMed] 